\title{
PENGEMBANGAN KAMPUNG SENI MELALUI SANGGAR SENI LINTAS GENERASI
}

\author{
Welly Suryandoko dan Agus Suwahyono \\ Universitas Negeri Surabaya \\ wellysuryandoko@unesa.ac.id
}

\begin{abstract}
ABSTRAK
Pada pelaksanaan KKN-PPM ini mengutamakan penerapan teori dan praktek seni teater berupa pelatihan-pelatihan berperan dan bermain Seni Teater Tradisional Ludruk secara utuh di sekitar desa Canggu Kecamatan Jetis Kabupaten Mojokerto wilayah yang dekat dengan Ludruk Karya Budaya. Selain memberikan pelatihan ketrampilan ludruk untuk Sanggar Ludruk Karya Budaya, Sanggar Ludruk Remaja dan Sanggar Ludruk Anak. di Desa Canggu. Berawal dari pelatihan Seni Teater Tradisional Ludruk diharapkan warga Desa Canggu umumnya atau para peserta pelatihan tersebut dapat menjadi generasi penerus Ludruk baru yang dapat menunjang kekuatan wisata kampong seni di desa. Target dari kegiatan KKN adalah mengubah mitra atau khalayak sasaran yaitu Sanggar Ludruk Karya Budaya, Sanggar Ludruk Remaja dan Sanggar Ludruk Anak Desa Canggu Kecamatan Jetis, Mojokerto yang awalnya kurang produktif sacara ekonomi melalui pelatihan ketrampilan Seni Teater Tradisional Ludruk ini diharapkan dapat menjadi destinasi andalan Desa Canggu. Luaran (output) yang akan dihasilkan setelah kegiatan ini dilaksanakan yang utama terwujudnya Desa Wisata yang mewadai Ludruk lintas generasi andalan Desa Canggu. Senyampang mewujudkan Sanggar Seni Ludruk Lintas Generasi Tim PMM juga memberikan pelattihan untuk menghasilkan pengembangan destinasi desa wisata sebagai kampung Ludruk. Mendaftarkan Desa Canggu sebagai Kampung seni Ludruk Jawa Timur
\end{abstract}

Kata kunci: Kampung Seni, Desa Canggu, Sanggar Seni

\section{ABSTRACT}

In the implementation of KKN-PPM, the application of theatrical arts theory and practice in the form of trainings to play and play the art of Ludruk Traditional Theater in full around the village of Canggu in Jetis Subdistrict, Mojokerto Regency, which is close to Ludruk Karya Budaya. In addition to providing ludruk skills training for Sanggar Ludruk Karya Budaya, Sanggar Ludruk Remaja and Sanggar Ludruk Anak. in Canggu Village. Starting from the training of the Ludruk Traditional Theater Art, it is hoped that the residents of Canggu Village in general or the training participants can become the next generation of Ludruk who can support the strength of the tourism village in the village. The target of KKN activities is to change the target partners or audiences, namely Sanggar Ludruk Karya Budaya, Sanggar Ludruk Remaja and Sanggar Ludruk Anak Desa Canggu, Jetis Subdistrict, Mojokerto, which initially were not economically productive through the art training of Ludruk Traditional Theater. . The output (output) that will be produced after this activity is carried out is the main realization of the Tourism Village which is the mainstay of the 
Canggu Village's mainstay crossing. Senyampang embodies the Cross-Generated Ludruk Art Studio The PMM team also provides training to produce the development of tourist village destinations as Ludruk village. Registering Canggu Village as the village of Ludruk East Java.

Keywords: Kampung Seni, Canggu Village, Art

\section{PENDAHULUAN}

Kampung sebagai ruang kota dapat menjadi bagian penting dalam pengembangan kota kreatif. Kampung kota merupakan bagian yang tidak dapat dipisahkan dari kota yang merupakan identitas yang khas dalam kota. Kota hanya bisa hidup karena kampung sementara kampung juga bisa hidup karena berada di seting kota (Setiawan, 2010). Kampung juga bisa dikatakan sebagai ruang kreatif kota yang dapat menjadi pusat kegiatan dan perekonomian kreatif. keberadaraan kampung menjadi pondasi dalam struktur perkembangan kota. Kampung juga sangat berperan dalam perekonomian kota dengan pendekatan ekonomi kreatif dan pariwisata. Sebagai salah satu wujud dari ruang kreatif kota, maka kampung harus memiliki identitas dan kekhasan sebagai tempat yang dapat mandiri dan mendukung konsep dari suatu kota. Kabupaten Mojokerto terdiri atas 18 kecamatan, yang dibagi lagi atas sejumlah desa dan kelurahan. Kini banyak gedung dan kantor pemerintahan yang dipindahkan ke Kota Mojosari, sebelah timur Kota Mojokerto. Bagian selatan Kabupaten Mojokerto berupa pegunungan, dengan puncak Gunung Welirang (3.156 m) dan Gunung Anjasmoro (2.277 m). Di Mojokerto terdapat kecamatan Jetis, yang menjadi pusat kelompok seni teater tradisonal Ludruk yaitu Ludruk Karya Budaya. Tepatnya di Desa Canggu Kecamatan Jetis Kabupaten Mojokerto, di Jawa Timur Ludruk Karya Budaya menjadi barometer dalam perkembangan Ludruk selain Ludruk Cak Kartolo dan Ludruk lainnya. Hal ini didapatkan dari keuletan pimpinan ludruk tersebut yaitu Edy Karya yang mampu mengkreasikan seni tersebut dengan konsep yang kekinian, baik lawawak, cerita dan unsur lainnya. Selain itu, Edy Karya selalu membuka diri dengan mengembangkan Ludruk dengan memberikan pembelajaran kepada anak remaja, sekolah dasar dan dewasa di wilayah desa tersebut. Kratifitas inilah yang perlu diekspose dengan mengembangkan kampong seni. 
Salah satu indikator kota kreatif adalah terdapatnya ruang-ruang kreatif yang dapat merangsang munculnya ide-ide kreatif dan inovasi. Kampung sebagai salah satu bentuk ruang kreatif di perkotaan. Yogyakarta memiliki banyak kampung yang memiliki karakteristik unik yang dapat dijadikan sebagai kampung kreatif. Kampung "Seni” Melalui Sanggar Lintas Generasi merupakan satu-satunya kampung yang memilik branding sebagai kampung seni dengan potensi dibidang kesenian yang ada di perkotaan Mojokerto. Pada kampung ini terdapat banyak seniman yang menetap dan berkarya di sini. Seiring dengan perkembangan waktu mulai ada perkembangan dikampung ini terutama dengan pariwisata candi Majapahit, Kampung Seni dapat menambah ruang destinasi wisata. Berdasarkan hasil pengkajian potensi dan masalah maupun penggalian informasi dan aspirasi dari berbagai pihak, maka dapat dijelaskan gambaran permasalahan kunci yang dihadapi berikut prioritas penanggulangan masalah serta gambaran potensi unggulan beserta prioritas rencana pengembangannya adalah memperkuat keahlian berkesenian dengan menggali potensi daerah yang dimiliki oleh Desa Canggu. Salah satu potensi pengembangan keahlian bermain Seni Teater Tradisional Ludruk dengan menggali potensi daerah di Desa Canggu adalah memberikan pelatihan Seni Teater Tradisional Ludruk Ludruk yang menggali sumber daya Desa Canggu. Ketrampilan Ludruk tersebut diberikan kepada warga desa terutama yang berusia produktif yaitu:anak-anak, Remaja dan Dewasa

\section{METODE PENELITIAN}

Metode yang digunakan adalah metode pelaksanaan kegiatan untuk mengatasi permasalahan yang memuat tahapan berikut ini.

A. Persiapan dan Pembekalan

1. Koordinasi Tim Pengelola KKN-PPM Unesa 2017.

2. Rekrutmen mahasiswa semester VI sebagai peserta KKN dari Jurusan Pendidikan Seni Drama, Tari dan Musik Fakultas Bahasa dan Seni UNESA.

3. Observasi lokasi KKN.

4. Penyusunan Buku Pedoman.

5. Pendidikan dan Pelatihan bagi mahasiswa KKN-PPM Unesa 2018. 
6. Materi Pendidikan dan Pelatihan berupa: Sosialisasi Program KKN-PPM Unesa 2018 dan Teknik Seni Teater Tradisional Ludruk dan Pengembangan Kampung Seni.

B. Pelaksanaan

Langkah-langkah untuk mencapai hasil yang diharapkan dari tema KKNPPM tim pelaksana mengusulkan kepada mitra pembinaan pengembangan ekonomi kreatif melalui Produk Kerajinan dengan metode yang diterapkan yaitu:

1. Presentasi, berupa sajian penjelasan materi tentang : a) Penjabaran Teknik Bermain Ludruk; b) Praktek Jenis Ludruk ; c) Praktek jenis ludruk berdasarkan penyajian; d) Praktek alat musik Ludruk dan e) Praktek kostum dan make up Ludruk

2. Demonstrasi pertunjukan Ludruk dengan memperagakan langsung di hadapan peserta. Mulai dari persiapan tahap Ngremo, lawakan, Adegan hingga penyelesaiannya.

3. Latihan, yaitu: menerapkan langsung materi yang telah didapat melalui presentasi dan demonstrasi tersebut dengan latihan langsung dengan arahan dari mahasiswa KKN PPM. Setelah diperagakan oleh Tim, peserta (mitra) melakukan langkah- langkah yang telah diperagakan Tim dan tetap didampingi hingga terwujud hasil karya seni Ludruk berbagai jenis dari yang serupa dengan yang dibuat oleh Tim.

C. Langkah-langkah operasional yang diperlukan untuk mengatasi permasalahan yang dideskripsikan pada latar belakang.

1. Tahap observasi dan identifikasi permasalahan

2. Tahap sosialisasi program kegiatan KKN-PPM dengan melibatkan seluruh komponen pemerintah desa.

3. Tahap orientasi pelaksanaan lapangan melalui program pelatihan dan pendampingan mahasiswa peserta KKN-PPM.

4. Tahap implementasi program kegiatan KKN-PPM sesuai dengan tema yang diusulkan.

5. Volume pekerjaan dalam bentuk Jam Kerja Efektif Mahasiswa (JKEM). 
Tabel 1. Volume Pekerjaan Mahasiswa KNN-PPM Desa Canggu Kecamatan Jetis Kabupaten Mojokerto Jawa Timur

\begin{tabular}{|c|c|c|c|c|}
\hline No. & $\begin{array}{c}\text { Nama } \\
\text { Pekerjaan }\end{array}$ & Program Kegiatan & $\begin{array}{l}\text { Volume } \\
\text { (JKEM) }\end{array}$ & Ket \\
\hline 1 & $\begin{array}{l}\text { Pendidikan dan } \\
\text { Pelatihan }\end{array}$ & $\begin{array}{l}\text { a. Orientasi program dan Pembekalan } \\
\text { materi } \\
\text { b. Koordinasi kelompok dengan DPL } \\
\text { dan Pembagian tugas kerja } \\
\text { c. Tes Pendidikan }\end{array}$ & $\begin{array}{l}1 \\
2 \\
6\end{array}$ & $\begin{array}{l}2 \text { hari } \\
1 \text { hari } \\
1 \text { hari }\end{array}$ \\
\hline 2 & $\begin{array}{l}\text { Pelaksanaan } \\
\text { lapangan }\end{array}$ & $\begin{array}{l}\text { a. Orientasi lapangan, di lokasi KKN } \\
\text { b. Identifikasi dan validasi } \\
\text { permasalahan } \\
\text { c. Sosialisasi program kegiatan }\end{array}$ & $\begin{array}{l}6 \\
6 \\
6\end{array}$ & $\begin{array}{l}1 \text { hari } \\
1 \text { hari } \\
1 \text { hari }\end{array}$ \\
\hline 3 & $\begin{array}{l}\text { Pelatihan } \\
\text { Unsur Utama } \\
\text { Ludruk }\end{array}$ & $\begin{array}{l}\text { a. Pelatihan Remo, dan Lawakan } \\
\text { b. Penokohan dan adegan Ludruk }\end{array}$ & $\begin{array}{l}24 \\
24\end{array}$ & $\begin{array}{l}4 \text { hari } \\
4 \text { hari }\end{array}$ \\
\hline 4 & $\begin{array}{l}\text { Pelatihan } \\
\text { Unsur } \\
\text { Pendukung } \\
\text { Ludruk }\end{array}$ & $\begin{array}{l}\text { a. Pelatihan Musik Ludruk } \\
\text { b. Pelatihan Kostum dan Make up } \\
\quad \text { Ludruk }\end{array}$ & $\begin{array}{l}18 \\
24\end{array}$ & $\begin{array}{l}3 \text { hari } \\
4 \text { hari }\end{array}$ \\
\hline 5 & Evaluasi Hasil & $\begin{array}{l}\text { a. Penyebaran Instrumen Respon } \\
\text { Masyarakat } \\
\text { b. Pengolahan data responden } \\
\text { c. Perumusan hasil kegiatan dan } \\
\text { pelaporan }\end{array}$ & $\begin{array}{l}6 \\
6 \\
6\end{array}$ & $\begin{array}{l}1 \text { hari } \\
1 \text { hari } \\
1 \text { hari }\end{array}$ \\
\hline & & Jumlah & 150 & 25 hari \\
\hline & \multicolumn{2}{|c|}{ Total JKEM Mahasiswa } & \multicolumn{2}{|c|}{4500} \\
\hline
\end{tabular}

\section{PEMBAHASAN}

\section{Pendidikan dan Pelatihan}

Sosialisasi program Program KKN-PPM ini dimulai dengan penyebaran pengumuman kepada calon mahasiswa peserta KKN-PPM. Surat pengumuman ini disebarkan ke seluruh Fakultas di UNESA. Isi surat tersebut berupa: mengumumkan kepada seluruh mahasiswa UNESA bahwa akan ada KKN-PPM tematik, yang bertema "Pengembangan Kampung Seni Melalui Sanggar Seni Lintas Generasi”. Seluruh mahasiswa UNESA yang memprogram KKN terutama mahasiswa semester 7 diperkenankan mendaftar. Dikarenakan tema yang ditekankan adalah Seni Teater 
Tradisional Ludruk maka dalam rekruitmen ini diutamakan mahasiswa Jurusan Seni Drama, Tari dan Musik yang sudah memprogram mata kuliah Seni Karawitan, Tari Jawa Timur, Tata Teknik Pentas dan Cahaya, dan Teater Tradisional tetapi tidak menutup kemungkinan mahasiswa jurusan lain yang berkeinginan untuk mempelajari dan menerapkan kampung Seni Ludruk ini.

Rekruitmen calon peserta KKN-PPM ini selama bulan Januari hingga Maret 2018. Mahasiswa yang berminat mengikuti KKN-PPM dipersilakan mendaftar di LPPM UNESA sabagai lembaga resmi penyelenggara KKN regular. Selain mengajukan nama dan identitas diri lainnya, calon peserta diminta mengisi surat pernyataan bahwa bersedia mengikuti program KKN-PPM sampai selesai dan tidak perlu mengikuti program KKN regular UNESA. Dari pengumuman ini didapatkan 30 mahasiswa peserta KKN-PPM yang terdiri dari mahasiswa Jurusan Seni Drama, Tari, dan Musik

Pada tanggal 28 April 2017 ke 30 mahasiswa terebut berkumpul untuk mengikuti sosialisasi program KKN-PPM tematik dengan judul "Pengembangan Kampung Seni Melalui Sanggar Seni Lintas Generasi”. Acara sosialisasi ini dimulai pukul 09.00 hingga 12.00 dihadirii oleh Prof. Dr. Hj. Lies Amin, M.A., M.Pd dan Prof. Dr. Darni, M.Hum sebagai perwakilan dari LPPM UNESA. Prof. Dr. Hj. Lies Amin, M.A., M.Pd memaparkan program KKN UNESA secara umum, sesi kedua Prof. Dr. Darni, M.Hum menyampaikan detail kegiatan KKN-PPM dan kegiatan tambahan yang dilakukan saat praktik KKN-PPM, kemudian dilanjutkan oleh Welly Suryandoko, S.Pd., M.Pd sebagai pembimbing DPL memaparkan program dan kegiatan-kegiatan KKN-PPM di desa Canggu, Kecamatan Jetis, Kabupaten Mojokerto

Secara keseluruhan mahasiswa peserta KKN-PPM ini antusias dan bersemangat untuk mengikuti program KKN-PPM ini. Hal ini disebabkan KKN-PPM ini merupakan KKN tematik yang memfokuskan pada peningkatan bermain seni ludruk dan pengembangan sanggar seni di desa Canggu. Penerapan praktik pelatihan ludruk ini telah dipelajari dalam mata kuliah Teater Tradisional, Seni Peran, Seni Tari dan Karawitan yang sudah ditempuh semua mahasiswa Jurusan Sendratasik pada semester 3. Sehingga KKN-PPM ini merupakan penerapan ilmu Seni pertunjukan yang didalamnya memuat Seni Karawitan, Tari Jawa Timur, Tata Teknik Pentas dan Cahaya, 
dan Teater Tradisional. Dengan demikian mahasiswa dapat membagi ilmu yang didapatkan di bangku kuliah langsung diterapkan ke masyarakat.
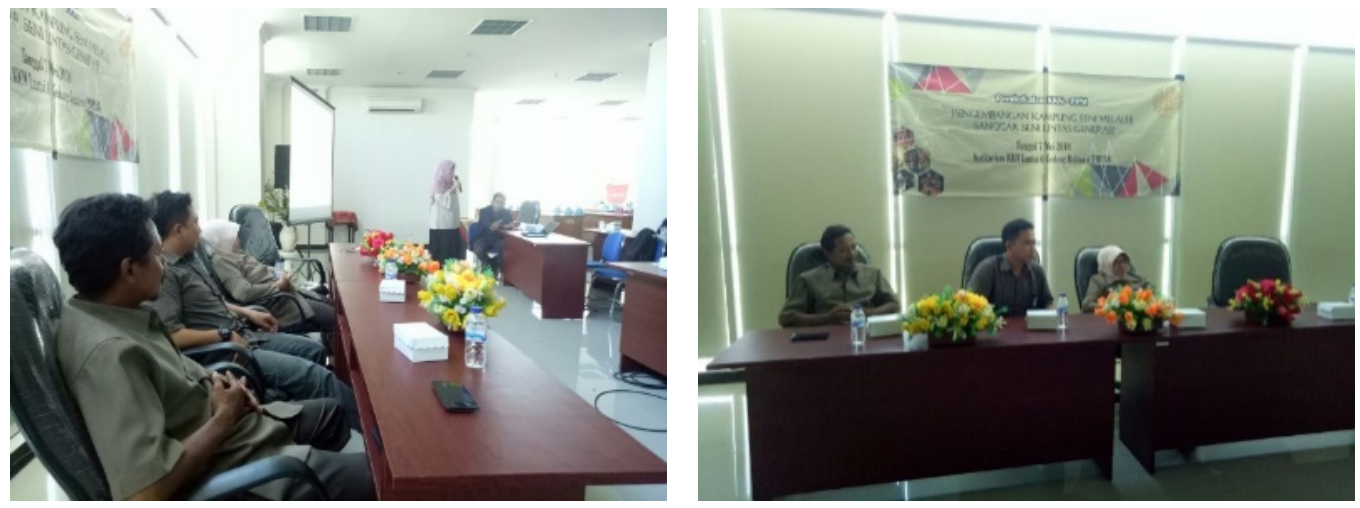

Gambar 1. Sosialisasi Program KKN PPM

Pada pertemuan ini mahasiswa memilih Koordinator Desa sebagai penghubung antara Dosen Pembimbing Lapangan, mahasiswa peserta KKN dan Perangkat Desa. Sebagai Koordinator Desa dipilih Fahmi Nizar Maulana dan wakilnya Rizka Widyana Kartika , keduanya dari Jurusan Seni Drama, Tari, dan Musik (Sendratasik).
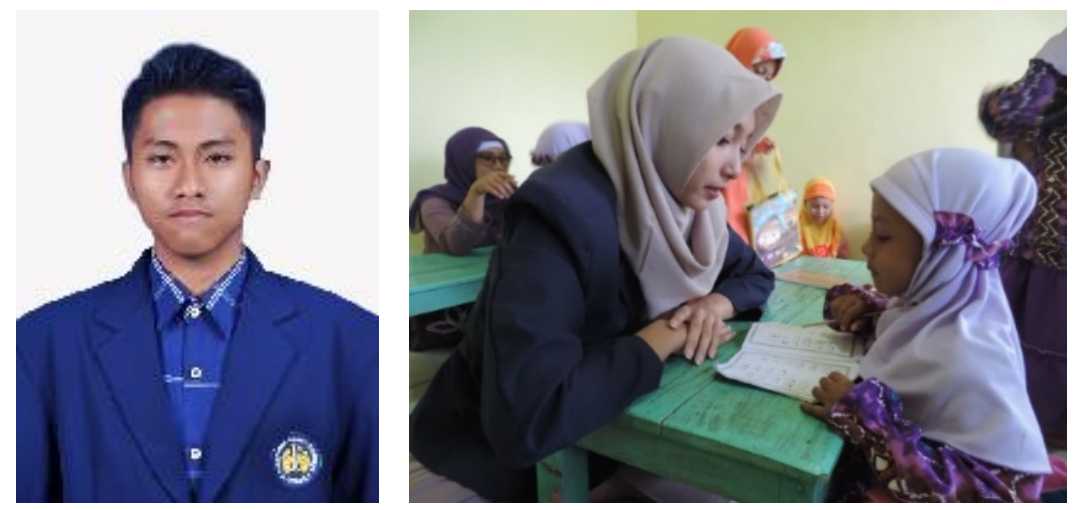

Gambar 2. Koordinator dan Wakil Kordinator Desa

\section{Pelaksanaan Lapangan}

Sela waktu pembekalan KKN-PPM masing-masing kelompok melakukan survey lapangan untuk mengumpulkan peserta pelatihan. Masing-masing kelompok diberikan tugas Dusun yang berbeda-beda. Kelompok 1 melakukan koordinasi dengan masyarakat Dusun Sukodono. Kelompok 2 berkoordinasi dengan masyarakat Dusun Singopadu. Tanggung jaawab masing-masing kelompok untu mencari peserta 
pelatihan sebanyak 20 anak-anak, 10 orang ibu-ibu PKK, 15 Remaja Karang Taruna Desa Canggu dan Bapak-bapak 10 Orang.

Sosialisasi program kegiatan KKN-PPM ini dilakukan baik secara formal maupun nonformal. Sosialisasi program secara formal dilakukan melalui agenda bulanan pertemuan PKK Desa Canggu. Mahasiswa KKN-PPM memberikan pemaparan program KKN-PPM mulai tujuan kegiatan, program kegiatan hingga hasil yang diharapkan. Sedangkan sosialisai non formal dilaksanakan dalam bentuk pelatihan make up di Kantor Desa Canggu.
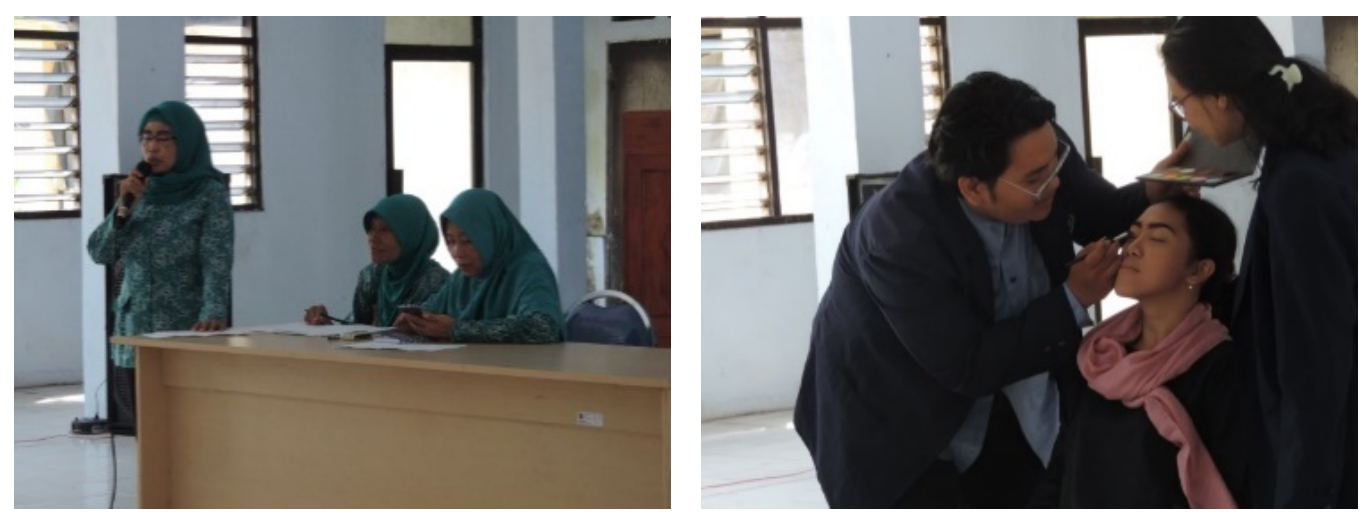

Gambar 3.Sosialisasi kegiatan KKN dengan cara Pelatihan Make Up

Setelah mahasiswa KKN-PPM mendapatkan data calon peserta pelatihan Ludruk. DPL sebagai Tim KKN-PPM mengundang Ketua LPPM untuk membuka secara resmi program kegiatan KKN-PPM "Pengembangan Kampung Seni Mealui Sanggar Seni Lintas Generasi” di Balai Desa Canggu pada tanggal 5 Agustus 2017 sebagai tanda bahwa KKN-PPM ini mulai dilaksanakan. Pembukaan ini selain dihadiri oleh Ketua LPPM, juga dihadiri oleh Prof. Dr. Hj. Lies Amin Lestari, M.A., M.Pd sebagai Ketua LPPM UNESA, Prof. Dr. Darni, M.Hum Sebagai Ketua Pusat Kuliah Kerja Nyata (KKN), Suyanto sebagai staf LPPM UNESA. Perangkat Desa yaitu: Kepala Desa, Drs. Sutjipto dan jajarannya juga menghadiri acara pembukaan ini. 


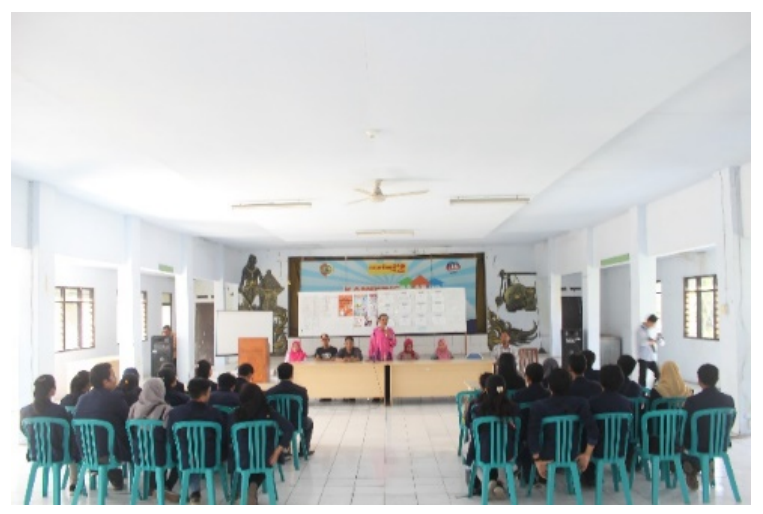

Gambar 4. Suasana Pembukaan KKN-PPM

\section{Kegiatan Pelatihan Ketrampilan Bermain Seni Ludruk}

Kegiatan pelatihan ketrampilan Seni Ludruk ini disesuaikan dengan kelompok KKN -PPM masing-masing beserta pesertanya, baik waktu maupun tempatnya. Masyarakat melakukan pelatihan di Sanggar Ludruk Karya Budaya dan Balai Desa sebagai tempat berkumpul sehingga di Balai Desa digunakan untuk beberapa kelompok sekaligus. Berikut jadwal pelaksanaan kegiatan pelatihan tiap-tiap kelompok

Berikut suasana pementasan Ludruk Lintas Generasi Desa Canggu, Kecamatan jetis, Kabupatan Mojokerto Kamis, 05 Juli 2018 di Halaman Pondok Jula-Juli Karya Budaya Desa Canggu. Mewujudkan "Pengembangan Kampung Seni Melalui Sanggar Seni Lintas Generasi”.

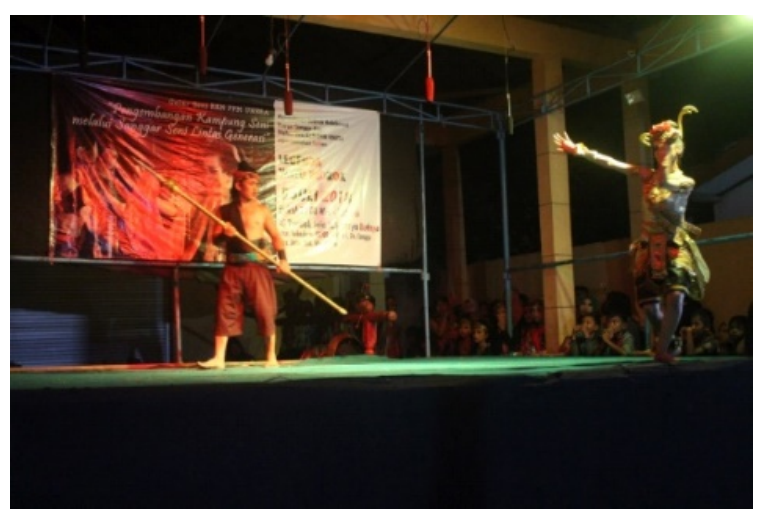

Gambar 5. Suasana Pementasan Ludruk Lintas Generasi

Secara garis besar mahasiswa perserta KKN-PPM aktif mengikuti setiap kegiatan latihan tari, lakon, karawitan, kesatuan pertunjukan ludruk dan mural tema 
ludruk. Hal ini dapat dilihat dari rata-rata jumlah kehadiran mahasiswa di setiap kegiatan. Sedangkan peserta kurang aktif dalam mengikuti kegiatan pelatihan ini, hal ini dapat dilihat dari rata-rata jumlah kehadiran peserta. Untuk keaktifan partisipasi mahasiswa dan peserta dapat dilihat pada tabel berikut ini.

Tabel 2. Keaktifan Mahasiswa dan Peserta dalam KKN-PPM Dusun Singopadu dan

Dusun Sukodono

\begin{tabular}{|c|c|c|}
\hline Kelompok KKN-PPM & Dusun Singopadu & Dusun Sukodono \\
\hline Jumlah Mahasiswa & 15 & 15 \\
\hline $\begin{array}{c}\text { Rerata Kehadiran } \\
\text { Mahasiwa }\end{array}$ & 15 & 15 \\
\hline Target Jumlah warga & 50 & 50 \\
\hline Rerata Kehadiran Warga & 40 & 35 \\
\hline
\end{tabular}

Kendala yang dihadapi menurut mahasiswa adalah peserta yang memiliki rutinitas yang bervariasi sehingga program pengecatan tidak semua warga bias ikut andil dalam kegiatan tersebut. Permasalahan yang terjadi adalah warga yang hadir pada pertemuan pertama terkadang tidak hadir pada pertemuan berikutnya dan baru hadir pada petermuan ketiga atau keempat sehingga setiap pertemuan mahasiswa KKN-PPM mengajarkan warga yang berbeda-beda. Hal ini sedikit menyulitkan mahasiswa KKN-PPM karena harus mengulang-ulang materi yang seharusnya berlanjut. Dampak dari keterlambatan pemberian materi tari, karawitan, lakon, kesatuan pertunjukan dan pengecatan tema ludruk tidak dapat diselesaikan dalam waktu yang singkat. Tim KKN-PPM Mahasiswa mengatur pelaksanaan pemberian materi tari, karawitan, lakon, kesatuan pertunjukan dan pengecatan tema ludruk dilaksanakan mengikuti jadwal kegiatan masayarakat. Latihan tari anak-anak dilaksanakan dua kali sebab anak-anak sedang libur sekolah. Latihan dilaksanakan siang hari dan malam hari, latihan tari ibu-ibu dilaksanakan malam hari, latihan karawitan “Gending” dilaksanakan malam hari, latihan lakon untuk warga remajja, dewasa dilaksanakan malam hari, latihan kesatuan pertunjukan ludruk dilaksanakan sore hari sampai malam hari, dan pengecatan tema ludruk dilakukan malam hari Bersama warga, mahasiswa dan karang taruna. Akhirnya mahasiswa KKN-PPM dan warga dapat menyelesaikan "Pengembangan Kampung Seni Melalui Sanggar Seni Lintas Generasi” pementasan lintas generasi dilaksanakan dan menghasilkan 
pengembangan kampung seni ini dengan baik. Camat, Kepala Desa, kepala LPPM UNESA dan Kapus KKN menyampaikan bahwa kampung seni ini berhasil. Namun, memerlukan tindak lanjut pendampingan. Agar kampung seni ini dikenal masyarakat luas dan warga Desa Canggu menjada dan mengembangkannya dengan baik. Bahkan media masa Mojokerto mendokumentasikan kegiatan KKN-PPM Pengembangan kampung seni melalui sanggar seni lintas generasi ini

\section{Kegiatan Penunjang Lainnya}

Selain mengikuti program kegiatan inti KKN-PPM berupa pelatihan karawitan, tari, lakon, mural ludruk, dan pentas ludruk lintas generasi tema para mahasiswa peserta KKN-PPM mengikuti beberapa program kegiatan Desa Canggu baik kegiatan rutin maupun insidentil. Kegiatan rutin yang diikuti oleh mahasiswa KKN-PPM adalah Bina TPA di Desa Canggu'. Kegiatan lainnya adalah Halal Bi Halal dikediman Kepada Desa canggu, Kepala Dusun dan Ketua Ludruk Karya Budaya.

1. Pendampingan mengajar MTQ

2. Halal Bihalal Bersama Kepala Desa dan Ketua Ludruk Karya Budaya

3. Pementasan KKN-PPM Pengembangan Kampung Seni Melalui Sanggar Seni Lintas Generasi

\section{Tahap Lanjutan (Pendampingan)}

Rencana selanjutnya setelah Pementasan Ludruk Lintas generasi KKN-PPM dengan tema "Pengembangan Kampung Seni Melalui Sangar Seni Lintas Generasi” sekaligus Penutupan secara resmi KKN- PPM adalah kegiatan pendampingan. Kegiatan ini merupakan kegiatan konsultasi hasil untuk pengembangan mural tema ludruk dan penataan Kampung Seni Ludruk. Pendampingan diperkirakan akan dilaksanakan sebanyak empat kali di masing-masing Dusun. Selama pendampingan mahasiswa akan memberikan masukan dan perbaikan mural dan dekorasi kampung seni Ludruk bahan disediakan oleh tim pelaksana. Selama proses pendampingan tidak semua peserta mengikuti kegiatan ini, pendampingan Pengembangan Kampung Seni ini hanya dilakukan oleh beberapa warga dan Karang Taruna yang benar-benar memiliki keinginan besar mengembangkan kampung seni Ludruk. 
Selama proses pendampingan Dekorasi dan Mural oleh Warga akan digunakan sebagai ilustrasi (foto dan video) media promosi. Media promosi ini diperlukan untuk menunjang pemasaran Kampung Seni di kemudian hari. Media promosi yang akan dibuatkan berupa: Video, Brosur, dan Dokumentasi foto melalui website, Instagram, facebook dan media lainnya. Diharapkan media tersebut dapat digunakan ketika mengikuti promosi sebagai Desa Wisata pada bidang Kampung Seni Ludruk.

Selama proses pelatihan dan pedampingan Lembaga Penelitian dan Pengabdian Masyarakat UNESA melakukan pemantauan (monev). Tim pelaksana juga mempersiapkan kunjungan tim pemantau baik dari tingkat UNESA maupun tingkat pusat DIKTI. Persiapan tersebut berupa pengumpulan dokumentasi kemudian akan diedit dan diperbaiki dalam bentuk video promosi. Sebagai umpan balik atas terselenggaranya Program Kegiatan KKN-PPM ini dan untuk mengetahui tanggapan Warga terhadap kegiatan pelatihan dan pengembangan kampung seni yang telah dilaksanakan oleh mahasiswa KKN-PPM di Desa Canggu Tim KKN-PPM menyebarkan Instrumen Respon Masyarakat. Penyebaran Instrumen ini dilakukan ketika kegiatan pendampingan berlangsung. Dari data yang diperoleh diharapkan mendapat masukan dan evaluasi kinerja mahasiswa KKN-PPM di lapangan. Data yang diperoleh akan diolah berupa prosentasi antara ya dan tidak. Data tersebut divisualkan dalan bentuk diagram untuk mempermudah pemahaman data. Tahapan terakhir dari kegiatan KKN-PPM ini adalah menyusun Laporan Akhir sebagai tanggung jawab atas kegiatan yang telah dilaksanakan sebelumnya. Laporan Akhir merupakan penyelesaian dari Laporan Kemajuan yang telah disusun ini. Laporan Akhir akan diselesaikan sebelum Kontrak Kerja berakhir yaitu pada bulan November 2018. Laporan Akhir akan disarikan dalam bentuk artikel ilmiah. Artikel ilmiah ini akan dipublikasikan dalam Seminar Nasional PPM yang diselengarakan oleh LPPM UNESA di bulan Desember 2018.

\section{PENUTUP}

KKN-PPM Dimulai dengan Sosisalisasi oleh Tim KKN-PPM dan Perwakilan LPPM UNESA Keseluruhan kegiatan mulai sosialiasasi hingga pembekalan dilaksanakan dengan lancar Seluruh mahasiswa yang terlibat antsusias terjuan ke lapangan untuk menerap ilmunya. Sebelum terjun ke lapangan, kelompok diberikan 
pengetahuan lengkap perihal Ludruk menuju "Pengembangan Kampung Seni Melalui Sangar Seni Lintas Generasi” .Perencanaan pembuatan Mural tema Ludruk dan Pementasan Ludruk Lintas Generasi. Selain menyusun modul mahasiswa KKN-PPM juga merancang materi pementasan Ludruk Lintas Generasi. Sebelum melatihkan karawitan, tari, lakon, mural tema ludruk dan kesatuan pertunjukan Ludruk untuk anak-anak, remaja (pemuda-pemudi Desa Canggu), ibu-ibu PKK, bapak-bapak anggota Rukun Tetangga dan Karang Taruna warga Canggu, Kecamatan Jetis, Kabupaten Mojokerto.

Anak-anak, remaja (pemuda-pemudi Desa Canggu), ibu-ibu PKK, bapak-bapak anggota Rukun Tetangga dan Karang Taruna serta mahasiswa KKN - PPM diasah kemampuan dan keterampilan karawitan, tari, lakon, mural tema ludruk dan kesatuan pertunjukan Ludruk. Secara garis besar pelaksanaan pelatihan Ludruk dan Mural Tema Ludruk ini berlangsung dengan lancar meskipun ada beberapa kendala Kendala yang dihadapi menurut mahasiswa adalah seluruh warga Desa Canggu dari Dusun Singopadu dan Dusun Sukodono. Kesulitan menyepakati waktu pelatihan diawal pelaksanan KKN-PPM tidak menjadi kendala berarti, sebab segera ditemukan solusisnya oleh mashasiswa KKN-PPM dengan pengaturan waktu sesuai dengan usia Warga dan waktu luang warga. Akhirnya mahasiswa KKN-PPM dan warga dapat menyelesaikan "Pengembangan Kampung Seni Melalui Sanggar Seni Lintas Generasi” pementasan lintas generasi dilaksanakan dan menghasilkan pengembangan kampung seni ini dengan baik. Camat, Kepala Desa, kepala LPPM UNESA dan Kapus KKN menyampaikan bahwa kampung seni ini berhasil. Namun, memerlukan tindak lanjut pendampingan

\section{DAFTAR RUJUKAN}

Bandem, I Made, Sal Murgiyanto, 1996. Teater Damasah Indonesia. Yogyakarta: Kanisius. Diterbitkan dalam kerjasama dengan Forum Apresiasi Kebudayaan Denpasar-Bali.

Mulyana, Anton R, Agus, Hairus, \& Joko, 2005. "Transvesti dalam Seni Pertunjukan” dalam GONG, Media Seni dan Pendidikan Seni edisi 75/VII/2005.

Supriyanto, Henri, 1992. Lakon Ludruk Jawa Timur. Jakarta: PT Gramedia Widiasarana Indonesia. 
2004. Kidungan Ludruk. Pemerintah Provinsi Jawa Timur bekerjasama dengan Widya Wacana Nusantara (Wicara).

Susanto, Eko Edy, 2014. Ludruk Karya Budaya. Mbeber Urip. Mojokerto: Paguyuban Ludruk “Karya Budaya” Mojokerto. 